\title{
The study of the directions for creation of employee benefits for pharmacy professionals and calculation of the possible cost of the individual components (options)
}

Aim. To study the directions for creation of employee benefits for pharmacy professionals and calculation of the possible cost of the individual components (options) in a pharmacy institution.

Materials and methods. The methodological basis of this study is general scientific and applied research methods, including methods of pairwise interactions, methods of multivariate analysis (Data Mining algorithms, Sequence, Association Rules, and Link Analysis), Friedman ANOVA for dependent samples. The abovementioned analyses were conducted using a StatSoft Statistica software package.

Results and discussion. Using the methods of multidimensional statistical analysis and Data Mining the interaction between satisfaction with employee benefits in a pharmacy institution by pharmacy professionals (PhP) and the need to provide or review the current employee benefits and general satisfaction with it have been studied. The analysis of association rules has made it possible to identify stable blocks of interactions between individual components (options), which are peculiar to different degree of PhP satisfaction with employee benefits, and determine factors associated to the greatest extent with the poor, medium, high and total PhP satisfaction with employee benefits.

Conclusions. The weight loads of individual components (options) of employee benefits have been calculated in order to form the balanced composition and cost. Based on the proposed scheme of the optimal filling of employee benefits the cost calculation has been made for their components (options), which provide the desired total cost of employee benefits estimated taking into account the data from the survey of PhP questionnaires in the pharmacy institutions of different forms of ownership. Four types of expenses have been offered depending on the position held by PhP.

Key words: pharmacy institution; social protection of pharmacy professionals; employee benefits; components (options) of employee benefits; pharmacy professionals

\section{М. В. Зарічкова}

Дослідження напрямків створення соціального пакету для спеціалістів фармації та розрахунку можливої вартості його окремих складових (опцій)

Мета роботи - вивчення напрямків створення соціального пакету для спеціалістів фрармації та розрахунку можливої вартості його окремих складових (опцій) в аптечному закладі.

Матеріали та методи. Методичною основою даного дослідження є загальнонаукові та прикладні наукові методи дослідження, в тому числі: методи дослідження парних взаємозв'язків, методи багатовимірного аналізу (алгоритми Data Mining, аналіз послідовних зв'язків і пошук асоціативних правил (Sequence, Association Rules, and Link Analysis)), дисперсійний аналіз Фрідмана пов'язаних вибірок. Зазначені аналізи виконувались в програмному пакеті StatSoft Statistica.

Результати та їх обговорення. 3 використанням методів багатовимірного статистичного аналізу та Data Mining досліджені взаємозв'язки між задоволеністю спеціалістами фрармації (СФ) соціальним захистом в аптечних закладах і необхідністю надання чи перегляду існуючого соціального пакету і загальну задоволеність ним. Аналіз асоціативних правил дозволив виявити стійкі блоки взаємозв'язків між окремими складовими (опціями), які характерні для різного ступеня задоволеності СФ соціальним пакетом, і вказати фрактори, які найбільшою мірою асоційовані з низькою, середньою, високою і з повною задоволеністю СФ соціальним пакетом.

Висновки. Розраховані вагові навантаження окремих складових (опцій) соціального пакету для фрормування його збалансованого складу та вартості. На підставі запропонованої схеми оптимального наповнення соціального пакету проведена калькуляція витрат на його складові (опції), які забезпечують бажану загальну вартість соціального пакету, оцінену на підставі даних анкетування СФ аптечних закладів різної фрорми власності. Запропоновано чотири типи витрат в залежності від рівня займаної СФ посади.

Ключові слова: аптечний заклад; соціальний захист спеціалістів фрармації; соціальний пакет; складові (опції) соціального пакету; спеціалісти фрармації

\section{М. В. Заричковая}

\section{Исследование направлений создания социального пакета для специалистов фармации и расчета возможной стоимости его отдельных составляющих (опций)}

Цель работы - изучение направлений создания социального пакета для специалистов фармации и расчета возможной стоимости его отдельных составляющих (опций) в аптечном учреждении. 
Материалы и методы. Методической основой данного исследования являются общенаучные и прикладные научные методы исследования, в том числе: методы исследования парных взаимосвязей, методы многомерного анализа (алгоритмы Data Mining, анализ последовательных связей и поиск ассоциативных правил (Sequence, Association Rules, and Link Analysis)), дисперсионный анализ Фридмана связанных выборок. Указанные анализы выполнялись в программном пакете StatSoft Statistica.

Результаты и их обсуждение. C использованием методов многомерного статистического анализа и Data Mining исследованы взаимосвязи между удовлетворенностью специалистами фармации (СФ) социальной защитой в аптечных учреждениях и необходимостью предоставления или пересмотра существующего социального пакета и общую удовлетворенность им. Анализ ассоциативных правил позволил выявить устойчивые блоки взаимосвязей между отдельными составляющими (опциями), которые характерны для разной степени удовлетворенности СФ социальным пакетом, и указать фракторы, которые в наибольшей степени ассоциированы с низкой, средней, высокой и с полной удовлетворенностью СФ социальным пакетом.

Выводы. Рассчитаны весовые нагрузки отдельных составляющих (опций) социального пакета для формирования его сбалансированного состава и стоимости. На основании предложенной схемы оптимального наполнения социального пакета проведена калькуляция затрат на его составляющие (опции), которые обеспечивают желаемую общую стоимость социального пакета, оцененную на основании данных анкетирования СФ аптечных учреждений различной формы собственности. Предложено четыре типа расходов в зависимости от уровня занимаемой СФ должности.

Ключевые слова: аптечное учреждение; социальная защита специалистов фрармации; социальный пакет; составляющие (опции) социального пакета; специалисты фрармации

Today, the problem of regulation and financial support of the social and economic problems in Ukraine becomes relevant. The pharmaceutical sector of the health industry is not an exception. It is characterized by the lack of significant range of unsolved social and economic problems. Thus, one of the areas of improvement of the system of social protection of pharmacy professionals (SPPhP) is introduction of employee benefits that are quite common in foreign pharmaceutical companies and consist of a rather wide range of options. However, for the Ukrainian pharmacy institutions such component as $\mathrm{SPPhP}$ is not widespread, and the social needs of the most vulnerable categories of pharmacy professionals $(\mathrm{PhP})$ are not sufficiently satisfied [1]. The abovementioned determines the relevance of the chosen subject matter of this article.

The aim of the article is to study the directions for creation of employee benefits for $\mathrm{PhP}$ and calculation of the possible cost of its individual components (options) in a pharmacy institution.

\section{Materials and methods}

For this study the methods of logical, historical, analytical analysis and sociological studies were used. The methodological basis of this study is general scientific and applied research methods, including methods of correlational relationships, methods of multivariate analysis (Data Mining algorithms, Sequence, Association Rules, and Link Analysis), Friedman ANOVA for dependent samples. The abovementioned analyses were conducted using a StatSoft Statistica software package. The multiple correspondence analysis was applied to study interdependence between components of PhP satisfaction with social protection. The correspondence analysis was conducted through singular decomposition of $18 \times 18$-dimensioned Burt matrix.

\section{Results and discussion}

The study of the current legislative and regulatory framework and scientific references regarding the research of the directions of improvement of the system of
$\mathrm{SPPhP}$ in Ukraine in modern conditions has shown polysystemic problematical character of its regulation and its implementation in the current conditions. Problems of social benefits and social protection of pharmacy professionals were studied in the works of the following scientists: Gromovyk B. P., Gudzenko O. P., Kabachna A. V., Kotvitska A. A., Mnushko Z. M., Nemchenko A. S., Parnovsky B. L., Ponomarenko M. S., Posylkina O. V., Slobodianiuk M. M., Tolochko V. M., Bratishko Yu. S., Kubarieva I. V. and others, but the issue of formation and implementation of the conception of SPPhP and particular directions of improvement of the system of social protection of pharmacy professionals in the current context have not been studied in their works [2-8]. However, despite the growing interest of scientists and practitioners to this subject, the nature of SPPhP, its impact on the staff motivation and efficiency of their activities are still studied poorly.

Based on the abovementioned information the subject studied is relevant and requires certain research, it will enable the system of SPPhP to be improved when implementing it to the practical activity of pharmacy institutions of Ukraine.

To substantiate the components (options) of employee benefits a questionnaire was conducted for $\mathrm{PhP}$ of pharmacy institutions of different forms of ownership. The study consisted of three phases according to the scheme shown in Fig. 1. This study is a part of the study regarding the improvement of the SPPhP system. Therefore, 100 pharmacy institutions, which became the baseline for analysis, were selected.

At the first phase PhP satisfaction with employee benefits functioning in the pharmacy institutions was studied. Respondents were asked to evaluate their satisfaction with employee benefits in percentage from 0 (total dissatisfaction) to 100 (total satisfaction) in step 10, i. e. the data obtained were considered as a value in the 11-point scale. During the study 9 respondents abstained from answering this question, while the opinions of other respondents were divided as follows (Fig. 2). 


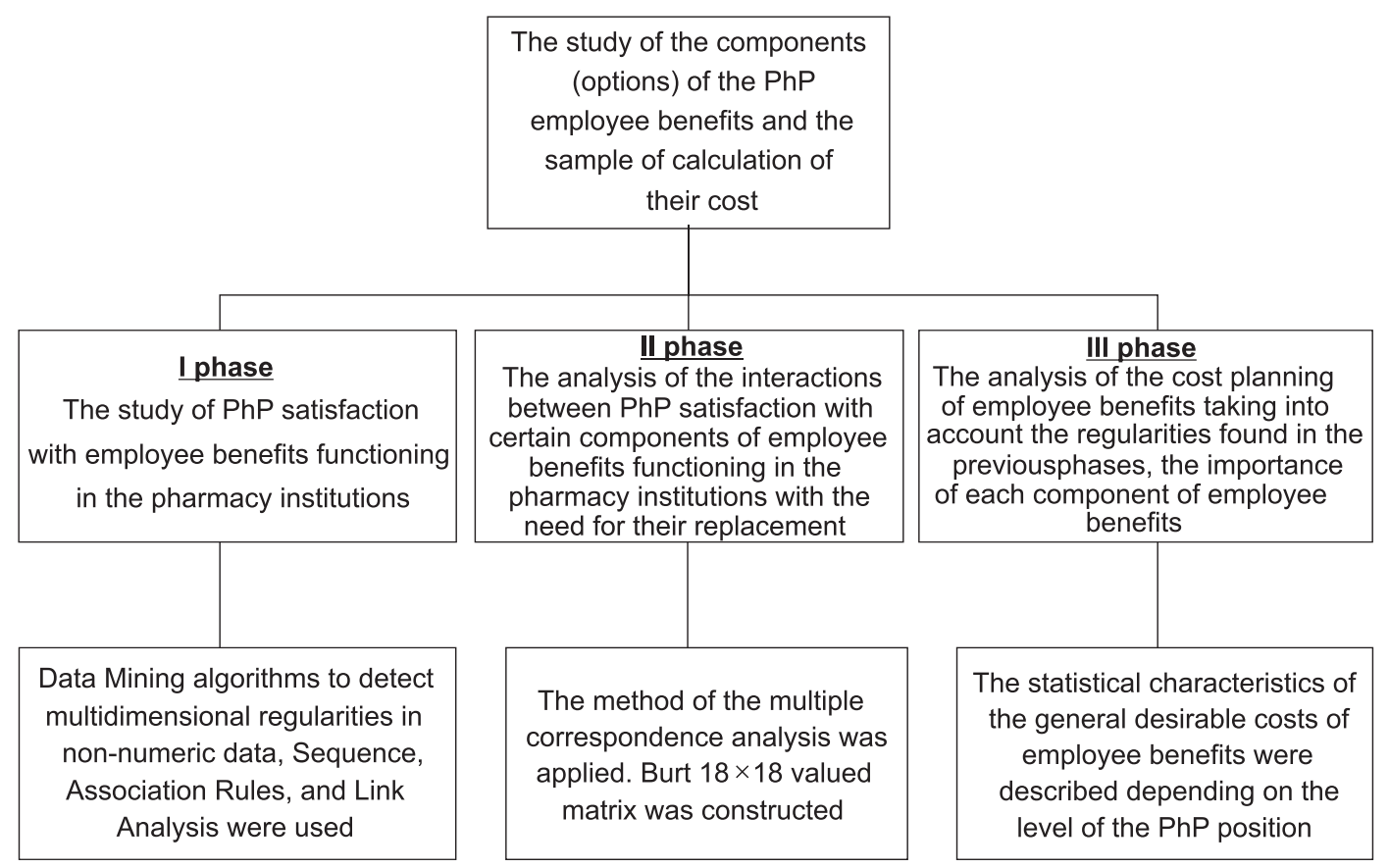

Fig. 1. Phasing of the study

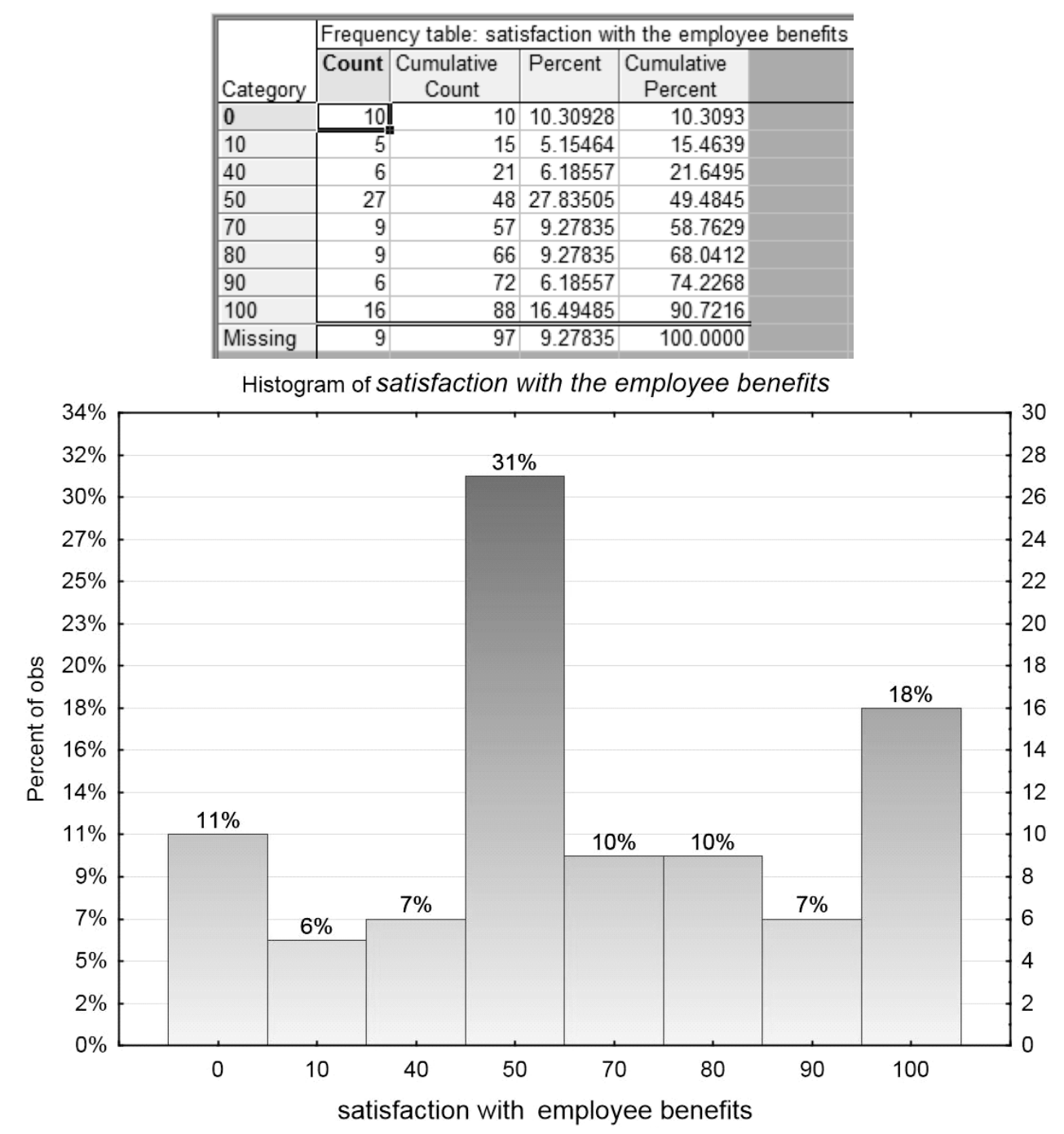

Fig. 2. Table of frequencies and the histogram of distribution (\%) of PhP satisfaction with the current employee benefits 
The results of the study of pairwise interactions of satisfaction with employee benefits in general and satisfaction with their components

\begin{tabular}{|l|c|c|c|c|}
\hline \multicolumn{1}{|c|}{$\begin{array}{c}\text { Components (options) } \\
\text { of employee benefits }\end{array}$} & $\chi 2, p$ & $G(p)$ & Correlation force \\
\hline Health insurance* & $\begin{array}{c}\chi 2=27.944 \\
\left(p=0.10 \times 10^{-3}\right)\end{array}$ & $\begin{array}{c}\tau=0.459 \\
\left(p=0.629 \times 10^{-7}\right)\end{array}$ & $\begin{array}{c}\mathrm{G}=0.604 \\
\left(p=0.629 \times 10^{-6}\right)\end{array}$ & medium \\
\hline Free meals & $\begin{array}{c}\chi 2=7.167 \\
(p=0.306)\end{array}$ & $\begin{array}{c}\tau=0.162 \\
(p=0.072)\end{array}$ & $\begin{array}{c}\mathrm{G}=0.227 \\
(p=0.072)\end{array}$ & none \\
\hline $\begin{array}{l}\text { Compensation for transport } \\
\text { expenses* }\end{array}$ & $\begin{array}{c}\chi 2=17.347 \\
(p=0.008)\end{array}$ & $\begin{array}{c}\tau=0.340 \\
\left(p=0.248 \times 10^{-3}\right)\end{array}$ & $\begin{array}{c}\mathrm{G}=0.459 \\
\left(p=0.248 \times 10^{-3}\right)\end{array}$ & weak \\
\hline $\begin{array}{l}\text { Payment for mobile } \\
\text { communication* }\end{array}$ & $\begin{array}{c}\chi 2=31.399 \\
\left(p=0.20 \times 10^{-4}\right)\end{array}$ & $\begin{array}{c}\tau=0.393 \\
\left(p=0.430 \times 10^{-6}\right)\end{array}$ & $\begin{array}{c}\mathrm{G}=0.569 \\
\left(p=0.430 \times 10^{-6}\right)\end{array}$ & medium / weak \\
\hline $\begin{array}{l}\text { Payment for additional } \\
\text { services (fitness-centre, etc.) }\end{array}$ & $\begin{array}{c}\chi 2=18.909 \\
(p=0.004)\end{array}$ & $\begin{array}{c}\tau=0.133 \\
(p=0.170)\end{array}$ & $\begin{array}{c}\mathrm{G}=0.185 \\
(p=0.170)\end{array}$ & none \\
\hline
\end{tabular}

Note: $\chi 2$ - is the calculated value of maximum likehood $\chi 2$ test; $t$ - is the Kendall rank correlation coefficient; $\mathrm{G}$ - is the Gamma rank correlation coefficient; $\mathrm{p}$ - is the statistical significance level; ${ }^{*}$ is the significant relationship of the general satisfaction with employee benefits.

The study showed that most respondents rated their satisfaction at the level of $50 \%$. The number of responses in the categories of "total satisfaction" and "total dissatisfaction" was quite weighty. Due to the small number of intermediate values the satisfaction rate was considered at four levels in the further analysis: insufficient and total dissatisfaction (from 0 to $40 \%$ ), average $(50 \%)$, high $(60 \div 80 \%)$ and total satisfaction $(90 \div 100 \%)$. The interaction of the total satisfaction with employee benefits and the satisfaction with their certain components (options) was of the greatest interest. The most desirable components (options) among them were as follows: health insurance, compensation for transport expenses and mobile communication, payment for food (providing free lunches) and payment for additional services (sports, etc.) $[9,10]$.

Two tables were analyzed when studying pairwise interactions between the satisfaction with employee benefits and each of their components (options). The significance of the interactions in $4 \times 3$ conjugation tables was determined based on $\chi 2$ maximum authenticity criterion with $95 \%$ confidence interval. The correlation ratio was assessed using the rank coefficients of Kendall correlation $(\tau)$ and Gamma correlation $(\mathrm{G})$. The values of the correlation coefficients were interpreted in accordance with the Chaddock scale. The results of the analysis of pairwise interactions are shown in Tab. 1.

Thus, significant interactions with the general satisfaction with employee benefits were confirmed for such components (options) as health insurance, compensation for mobile communication and compensation for transportation expenses. Despite the high statistical significance of interactions none of the correlations found can be considered as strong ones.

Based on the results of the one-dimensional analysis conducted such options of employee benefits as payment for additional services and meals should not have a significant impact on $\mathrm{PhP}$ satisfaction with employee benefits in general.
However, the methods of studying the pairwise interactions do not take into account the interdependencies between the components (options) themselves, which form employee benefits. These methods do not also allow detecting multiple relationships, which include more than two indicators existing between the characteristics studied. For these purposes, it is necessary to apply methods of the multivariate analysis. As such methods, Data Mining algorithms, namely, Sequence, Association Rules, and Link Analysis were used. Various combinations of the baseline values containing up to 10 elements were studied with a minimum allowable support value of 0.05 in the confidence range from 0.80 to 1.00 . Totally, 432 association rules with at least $5 \%$ support at the baseline were found by the algorithm (Fig. 3).

The results can be clearly displayed by the web graph shown in Fig. 4, which is a transformation of association rules table (Fig. 3) into a graphic form.

The graph nodes are the values of the non-numeric indicators studied. The size of the nodes corresponds to the support (relative frequency) of each element at the baseline. The graph ribs connecting the nodes indicate that there is dependence between the values. The line thickness herewith corresponds to the relative support of each two-element association rule: the thicker ribs mean greater support (the detected pattern of relationship is observed in the data more often than the other ones). The color of the edges in the given graph displays the value of the interference for a pair of indicators. Thus, thicker and darker lines indicate more common and reliable, stable associations. Thin and light lines indicate that the association rule determined by the rib is not often observed in the data and has poor coverage.

Consequently, the graph obtained allows finding the most stable associations between $\mathrm{PhP}$ dissatisfaction with individual components (options) of employee benefits, which, in turn, are quite closely associated with the dissatisfaction with employee benefits in general (less than $40 \%$ ). The last regularity is obvious (dissatisfaction 


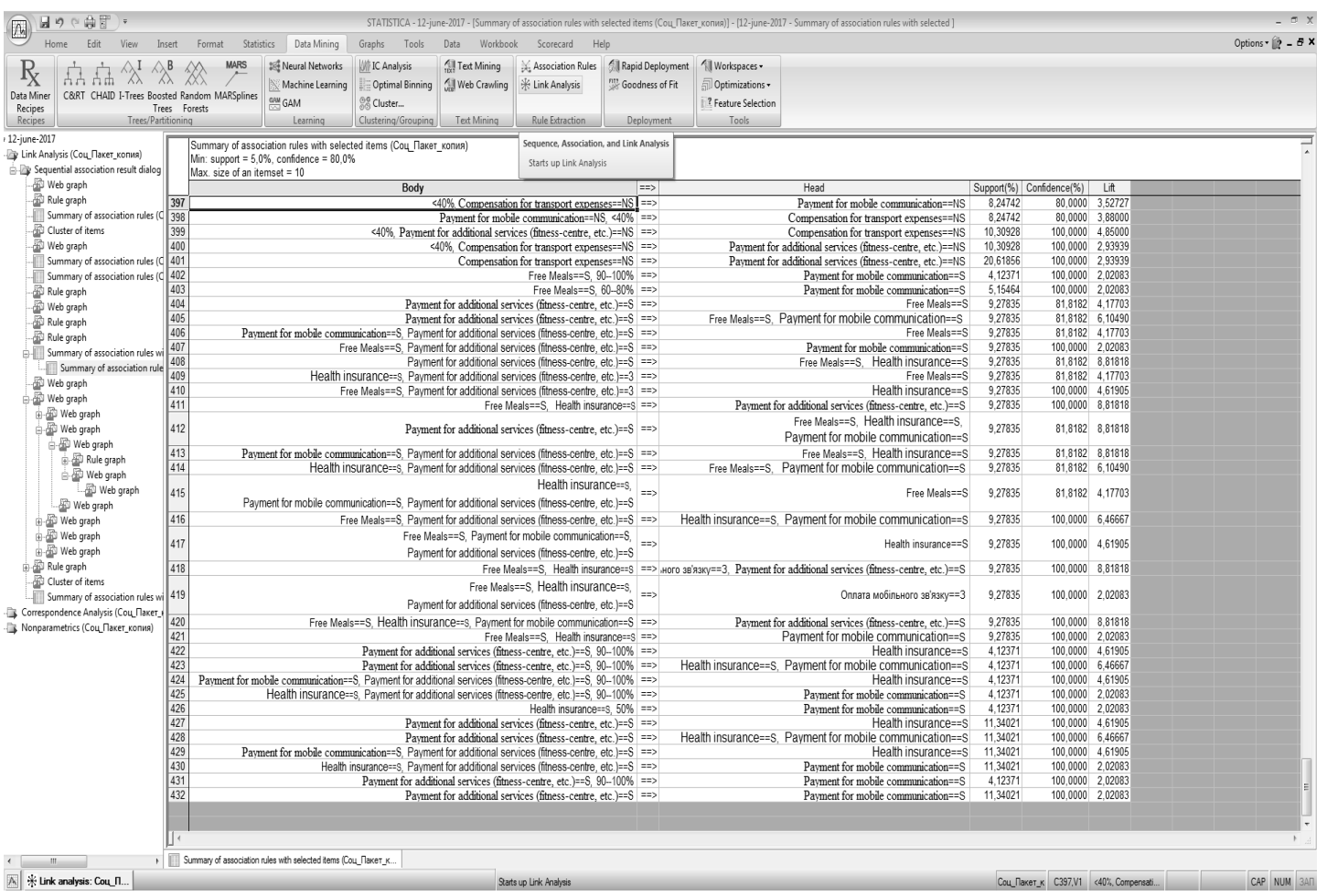

Fig. 3. The screenshot of the results of the Sequence, Association and Link Analysis module for the search of association rules determining $\mathrm{PhP}$ satisfaction with employee benefits

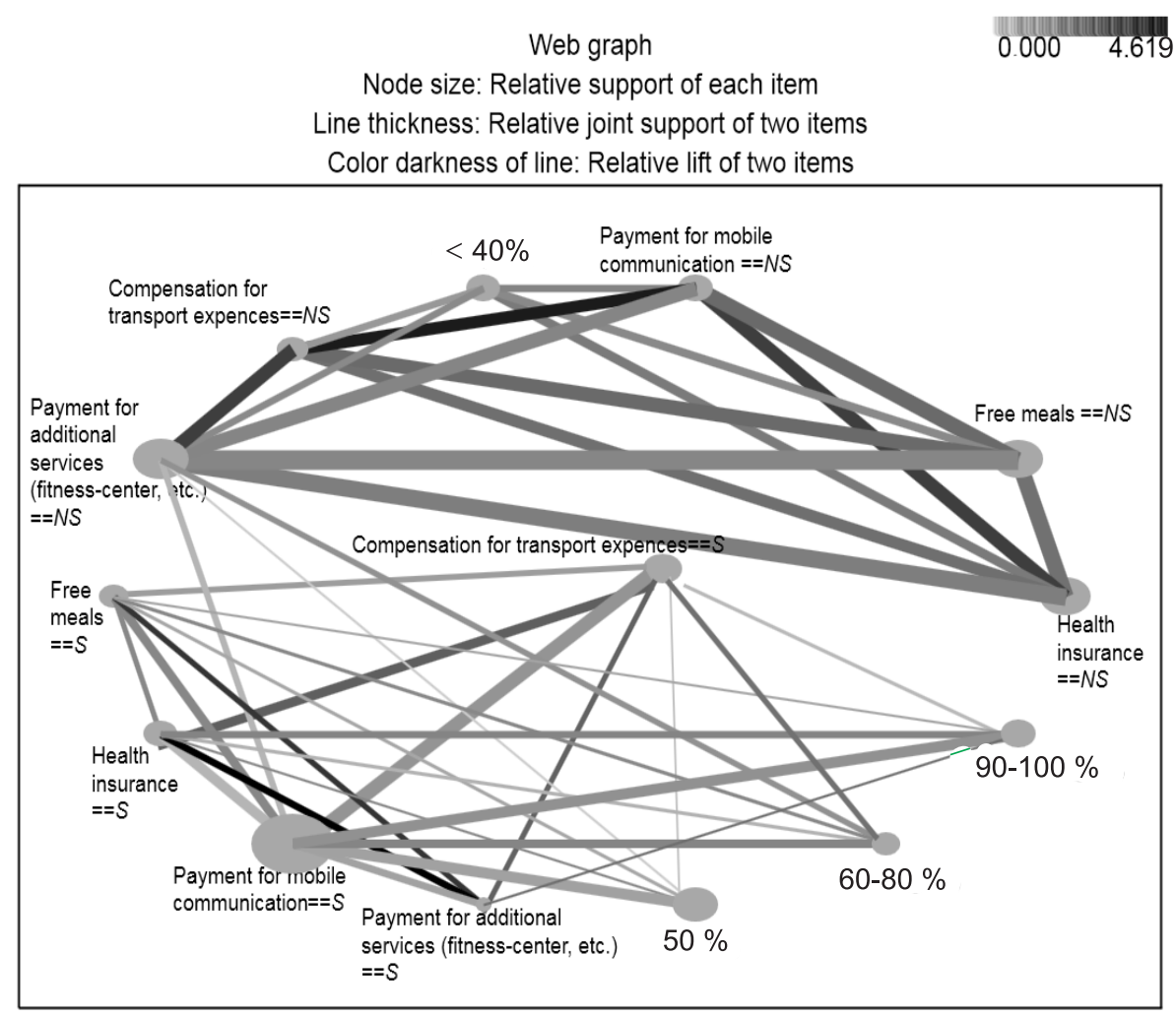

Fig. 4. The web graph of association rules of the study of the pairwise interactions when analyzing PhP satisfaction with employee benefits Symbols: $\mathrm{S}$ - is the satisfaction with the component (option) of employee benefits; NS - is the dissatisfaction with component (option) of employee benefits; $<40 \%$ - is the poor satisfaction with employee benefits in general; $50 \%$ - is the medium satisfaction with employee benefits; $60-80 \%$ - is the high satisfaction with employee benefits; $90-100 \%$ - is the total satisfaction with employee benefits 


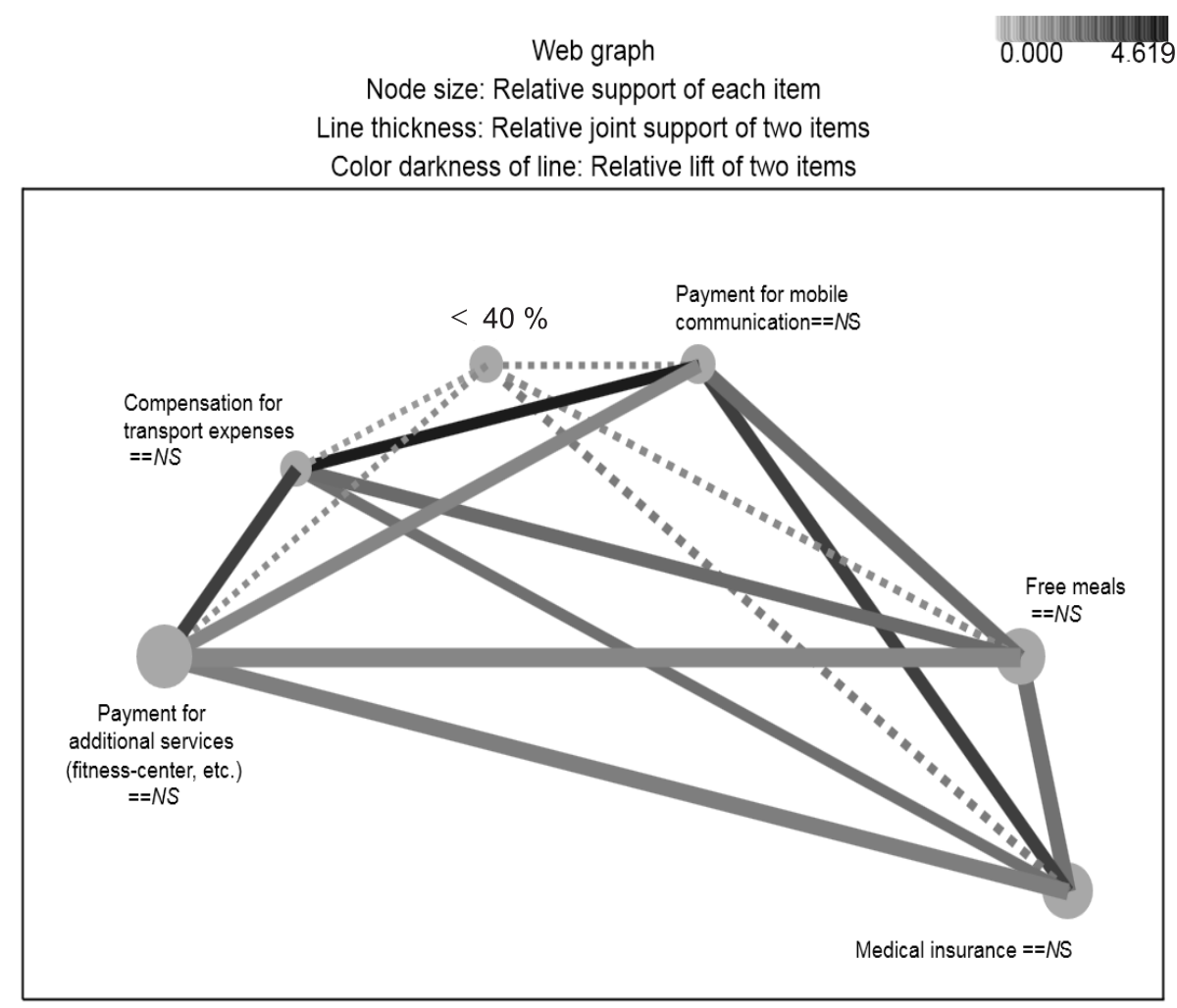

Fig. 5. The web graph of satisfaction with options of the employee benefits associated with PhP poor (40\%) satisfaction with employee benefits

with individual components (options) leads to dissatisfaction with the entire social package of benefits). Therefore, it can be stated that $\mathrm{PhP}$ dissatisfaction with one of the components of employee benefits will cause dissatisfaction with the other ones. The conclusion can be made that, firstly, components (options) of employee benefits are not interchangeable (for example, non-provision of health insurance cannot be compensated by free lunches or by a generous payment for mobile communication and transport expenses). This indicates that employee benefits should be considered as a set of measures for providing SPPhP, and implementation of some of its components (options) should be based on the relevant studies [11-14].

The only exception to this rule is $\mathrm{PhP}$ dissatisfaction with such a component (option) of employee benefits as payment for additional services (fitness centre, etc.). According to the analysis conducted (see Fig. 4), the dissatisfaction with the payment for such components (options) does not affect the satisfaction with employee benefits in general, both at the medium level $(50 \%)$ and at the high level (60-80\%).

The bottom side of the network graph (Fig. 4) discloses a similar block of mutually related positive assessments of satisfaction with certain indicidual components (options) of employee benefits and their association with the total, high or medium satisfaction with employee benefits in general. The stability and strength of the relationships of the options of employee benefits, both in the negative and in the positive assessment of $\mathrm{PhP}$ satisfaction with employee benefits, should be taken into account when planning the cost of employee benefits for $\mathrm{PhP}$.

Further, the analysis of association rules was conducted by parts, and it was detected which of the components were more important for providing the poor, medium, high or total satisfaction with employee benefits. Thus, Fig. 5 shows a part of the web graph of association rules describing the poor satisfaction with employee benefits in general.

The edges, which associate satisfaction below $40 \%$ with certain options of employee benefits, are marked by dotted lines. The diagram of association rules shown in Fig. 6 detects that the options, which are the most important, are the following: dissatisfaction with $\mathrm{PhP}$ health insurance and provision of free meals.

The network graph and the diagram of association rules connected with the medium $(50 \%)$ satisfaction with employee benefits are shown in Fig. 7 and 8. They demonstrate that the medium level of satisfaction with employee benefits is primarily associated with $\mathrm{PhP}$ satisfaction with the payment for mobile communication services. Association with satisfaction with other options is much lower.

A similar situation is observed with the $\mathrm{PhP}$ high $(60 \div 80 \%$ ) satisfaction with employee benefits (Fig. 9, $10)$. In this case the strongest association is characterized by the satisfaction with the payment for mobile communication services, and there is also an association with the dissatisfaction with the payment for additional services (fitness centre, etc.). However, in order to achieve high satisfaction with employee benefits compensation for transportation expenses is more important. 


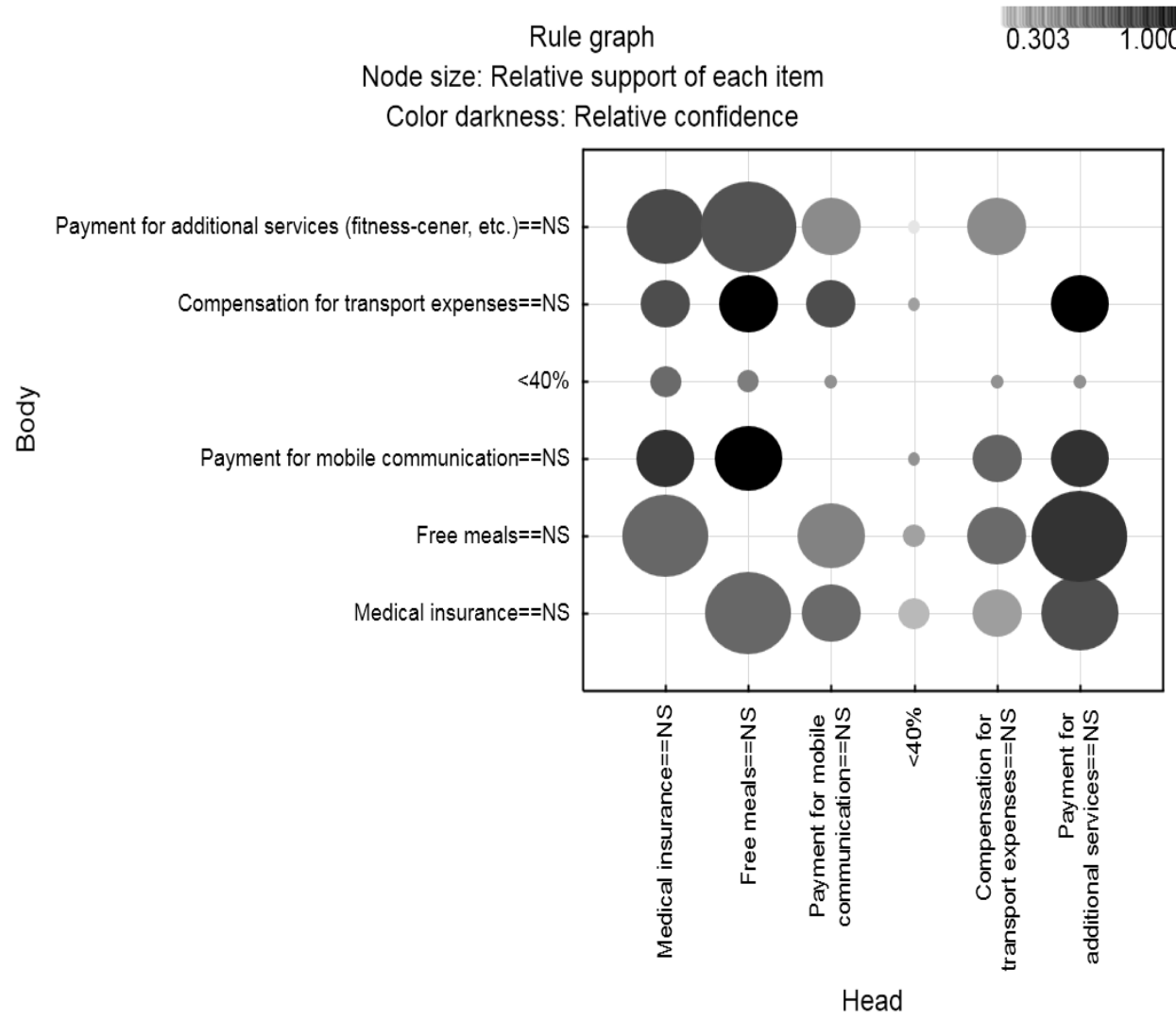

Fig. 6. The diagram of association rules of satisfaction with options of employee benefits connected with the $\mathrm{PhP}$ poor $(40 \%)$ satisfaction with employee benefits

Web graph

Node size: Relative support of each item Line thickness: Relative joint support of two items

Color darkness of line: Relative lift of two items

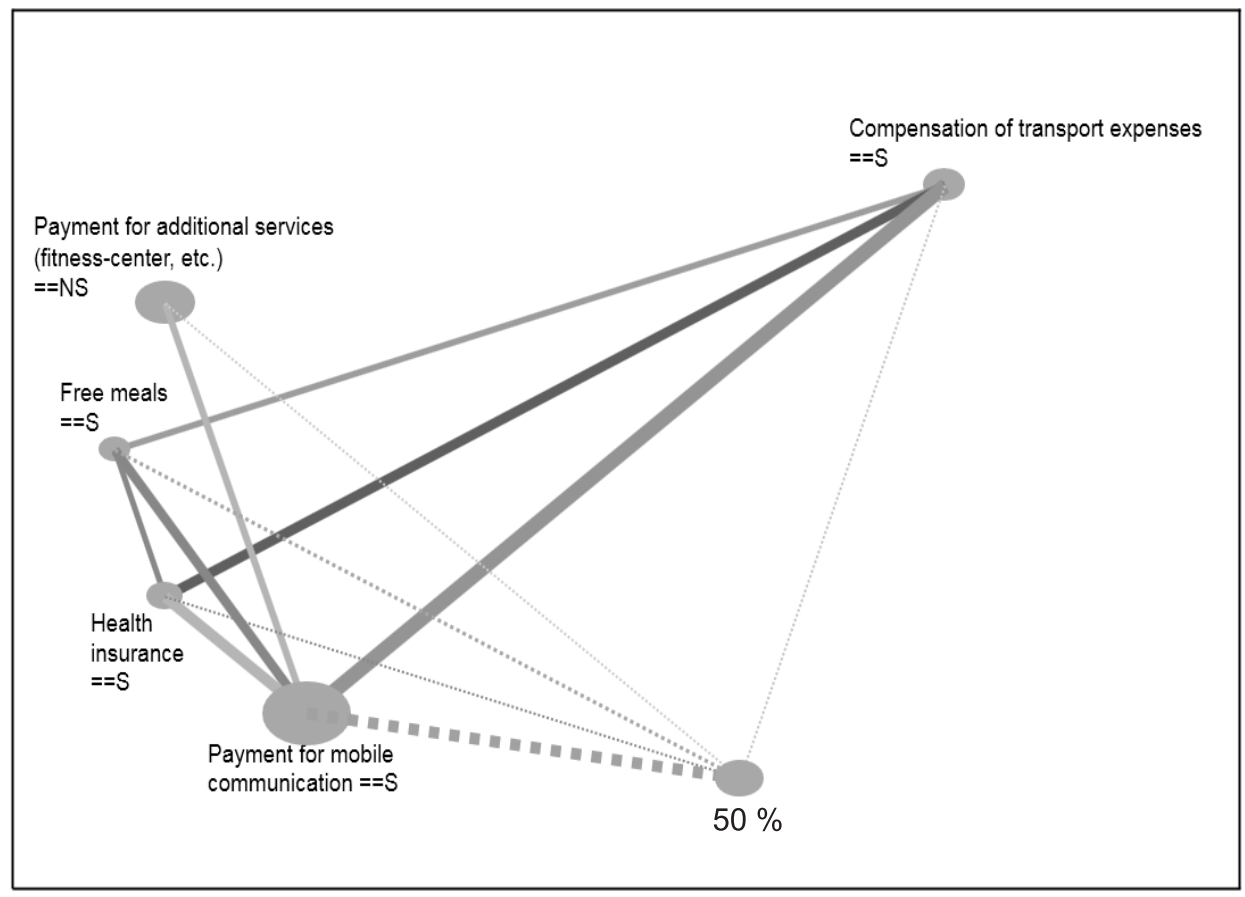

Fig. 7. The web graph of satisfaction with options of employee benefits associated with the average $(50 \%)$ satisfaction with employee benefits 


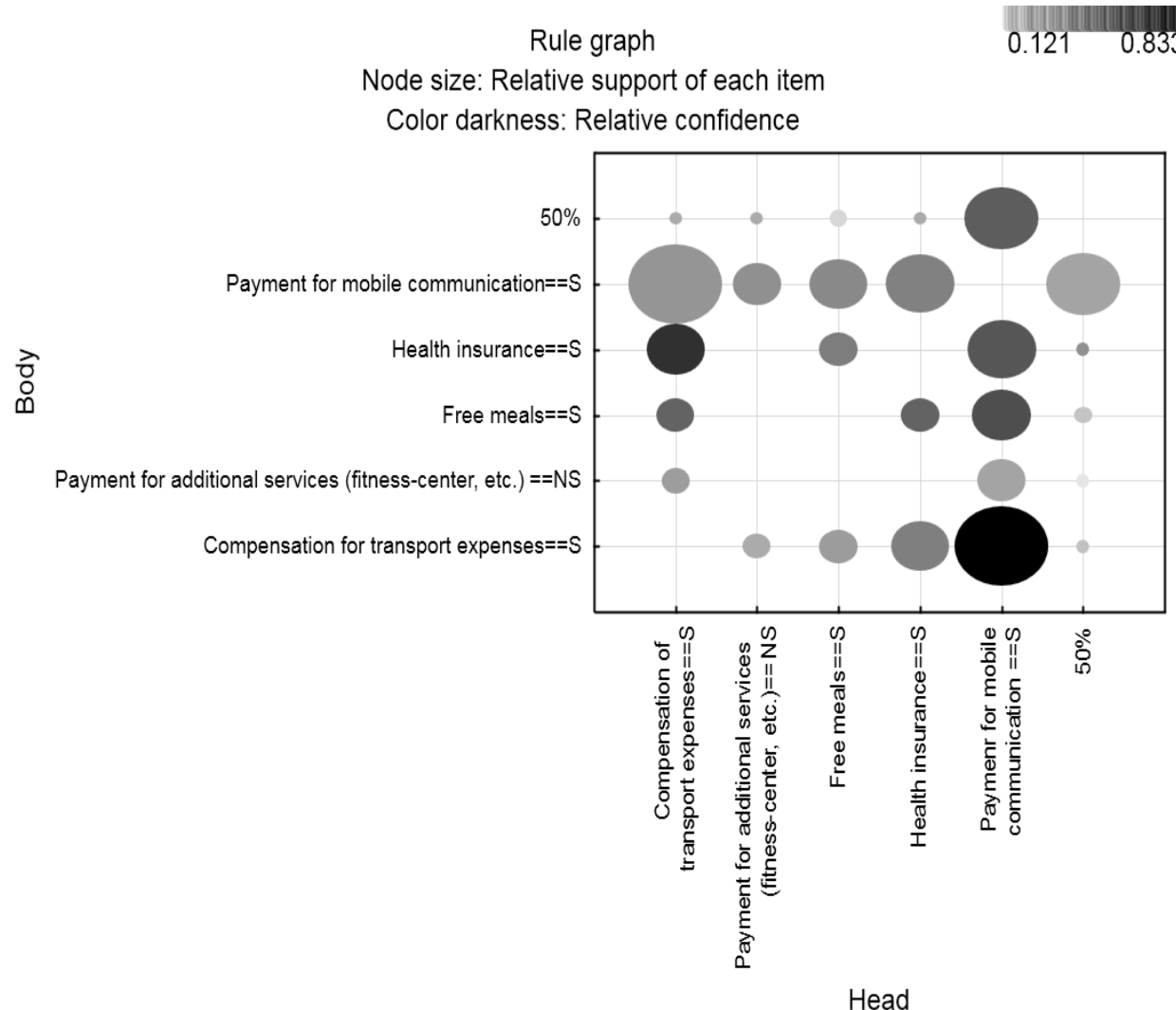

Fig. 8. The diagram of association rules of satisfaction with options of employee benefits connected with the $\mathrm{PhP}$ average $(50 \%)$ satisfaction with employee benefits

Web graph

Node size: Relative support of each item

Line thickness: Relative joint support of two items

Color darkness of line: Relative lift of two items

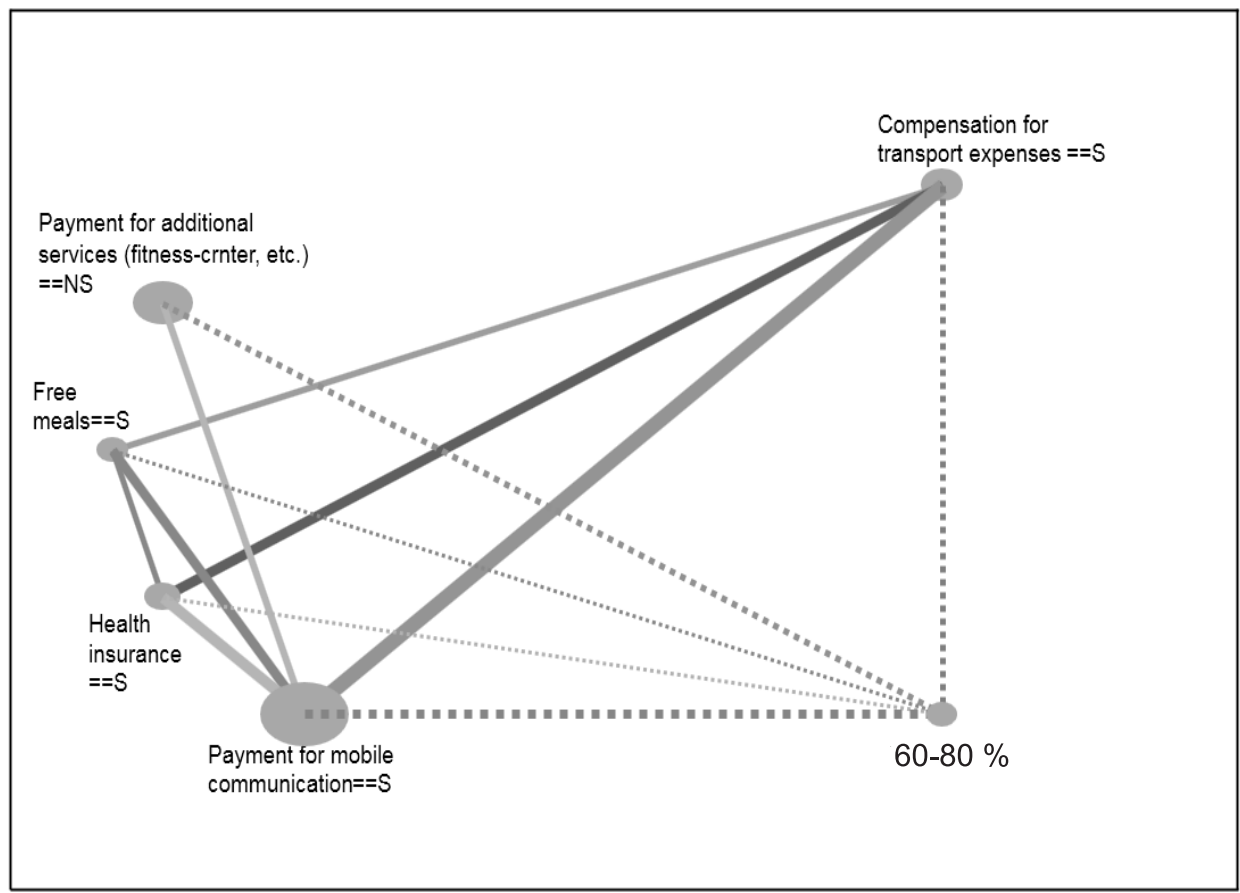

Fig. 9. The web graph of satisfaction with options of employee benefits associated with the PhP high $(60 \div 80 \%)$ satisfaction with employee benefits 


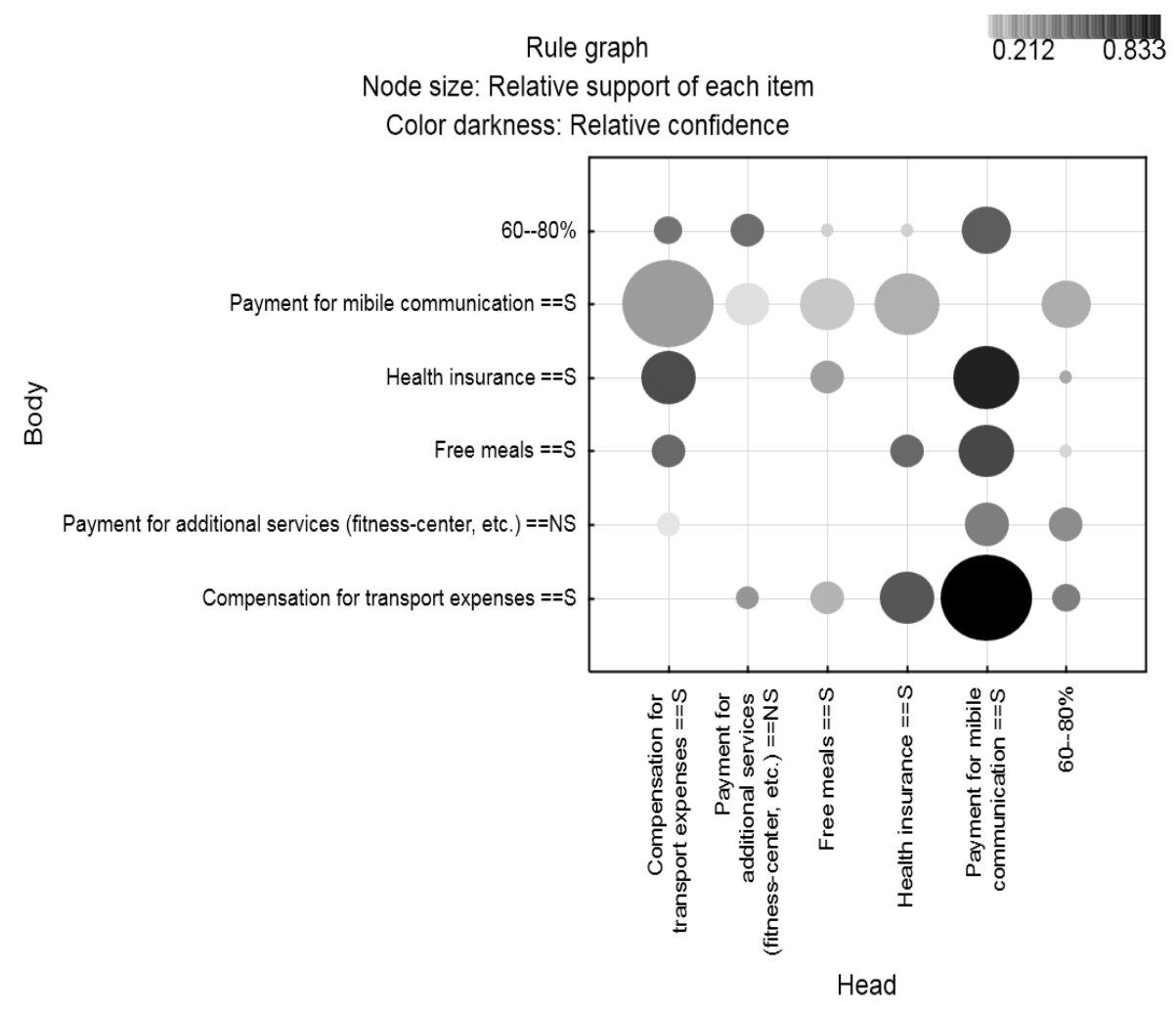

Fig. 10. The diagram of association rules of satisfaction with options of employee benefits connected with the PhP high $(60 \div 80 \%)$ satisfaction with employee benefits

The total satisfaction with employee benefits is related to the satisfaction with all of the components (Fig. 11). Moreover, the greatest association is observed with the satisfaction with the payment for mobile communication services; and a poorer association, but quite stable is with the satisfaction with health insurance (Fig. 11, 12).

Thus, the analysis of the sequential relationships and associative rules allowed detecting the multidimensional interactions between the level of satisfaction with employee benefits in general and the individual components (options). There were rather strong stable associations among the dissatisfaction with certain aspects of SPPhP, indicating the need for their joint accounting when forming employee benefits. There was a stable strong interaction between $\mathrm{PhP}$ satisfaction with the compensation for transport expenses and mobile communication services, indicating the need for a coherent planning of the costs for these options of employee benefits. The most important options were specified. Such options wer responsible for ensuring of different kind of satisfaction with social protection in general. Thus, $\mathrm{PhP}$ associated total, high and medium level of satisfaction with employee benefits with the compensation for mobile communication services. The poor satisfaction with employee benefits was associated with $\mathrm{PhP}$ dissatisfaction with provision of health insurance. In addition, it was shown that satisfaction with health insurance was an important component for achieving of the $\mathrm{PhP}$ total satisfaction with employee benefits.

The second phase consisted in the analysis of interactions between $\mathrm{PhP}$ satisfaction with the individual com- ponents of employee benefits functioning in the pharmacy institutions with their awareness of the need for their replacement. The desire to replace the existing employee benefits is another indicator of $\mathrm{PhP}$ satisfaction with social protection. According to the data analysis of the questionnaire $43 \%$ of the respondents consider that employee benefits used in their pharmacy institutions require replacement, $35 \%$ of $\mathrm{PhP}$ think that the current employee benefits are not subject to revision, $22 \%$ of $\mathrm{PhP}$ cannot decide what to answer (Fig. 13).

The apparent equal distribution of opinions indicates the lack of consistency in the field of $\mathrm{PhP}$ social guarantees provision. This fact confirms again the relevance of the issue of formation and implementation of a single standard for provision of SPPhP $[1-6,15,16]$.

The method of multiple correspondence analysis was used to study the interaction between the need to replace employee benefits and the satisfaction with their components. The Burt $18 \times 18$ valued matrix (Fig. 14) was constructed in order to carry out this method. It cross-stipulates the relationships between the indicators studied, which are fixed at three levels: satisfied, dissatisfied; difficult to answer; and the desire to replace employee benefits.

The multiple correspondence analysis allowed reducing the dimension of the original matrix with the maximum possible consistency between the indicators. The dimension of the final configuration space was chosen using Cattell's test based on the consideration of the so-called scree plot. According to Fig. 15 the optimal dimension for the projection is equal to 3 . In this case 
Web graph

Node size: Relative support of each item

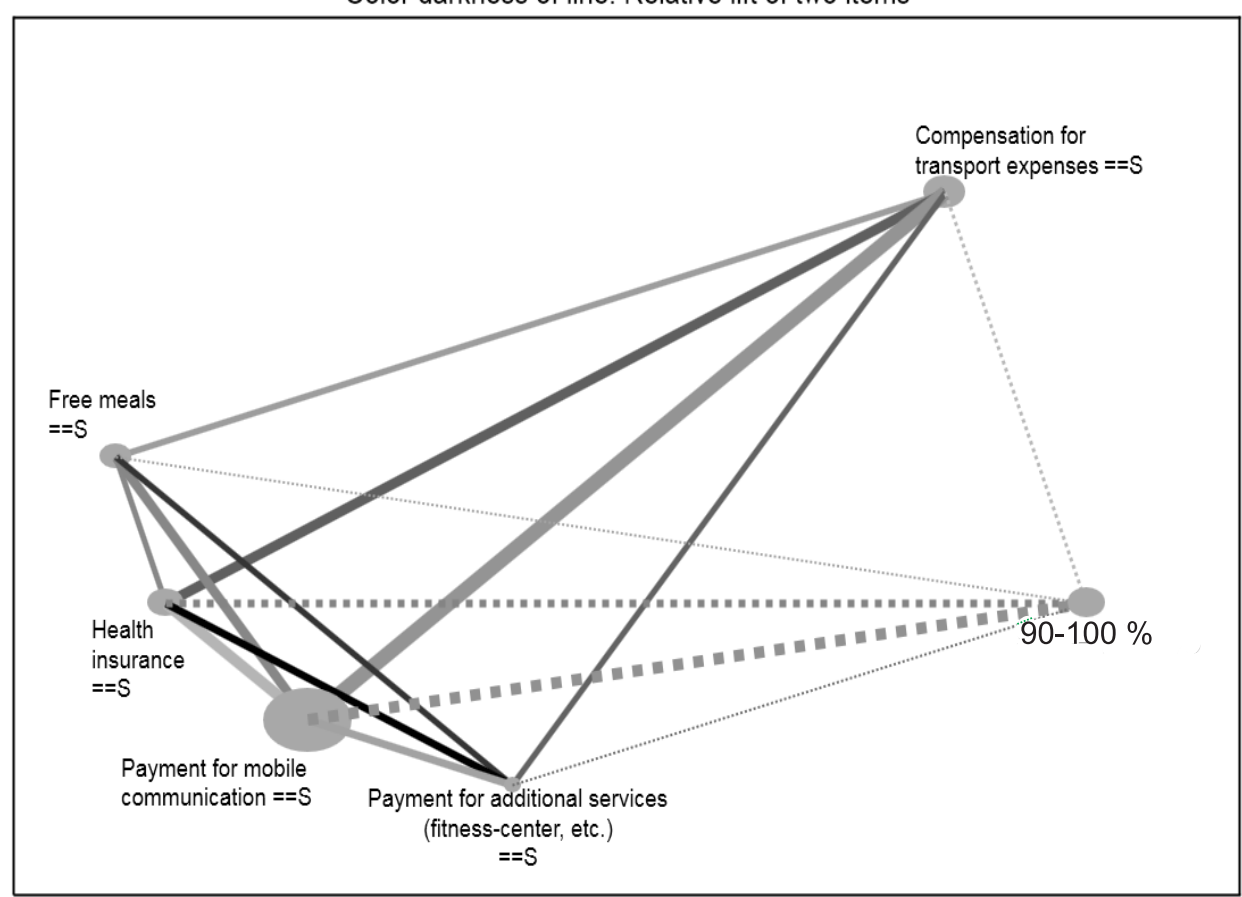

Fig. 11. The web graph of satisfaction with options of employee benefits connected with PhP total $(90 \div 100 \%)$ satisfaction with employee benefits

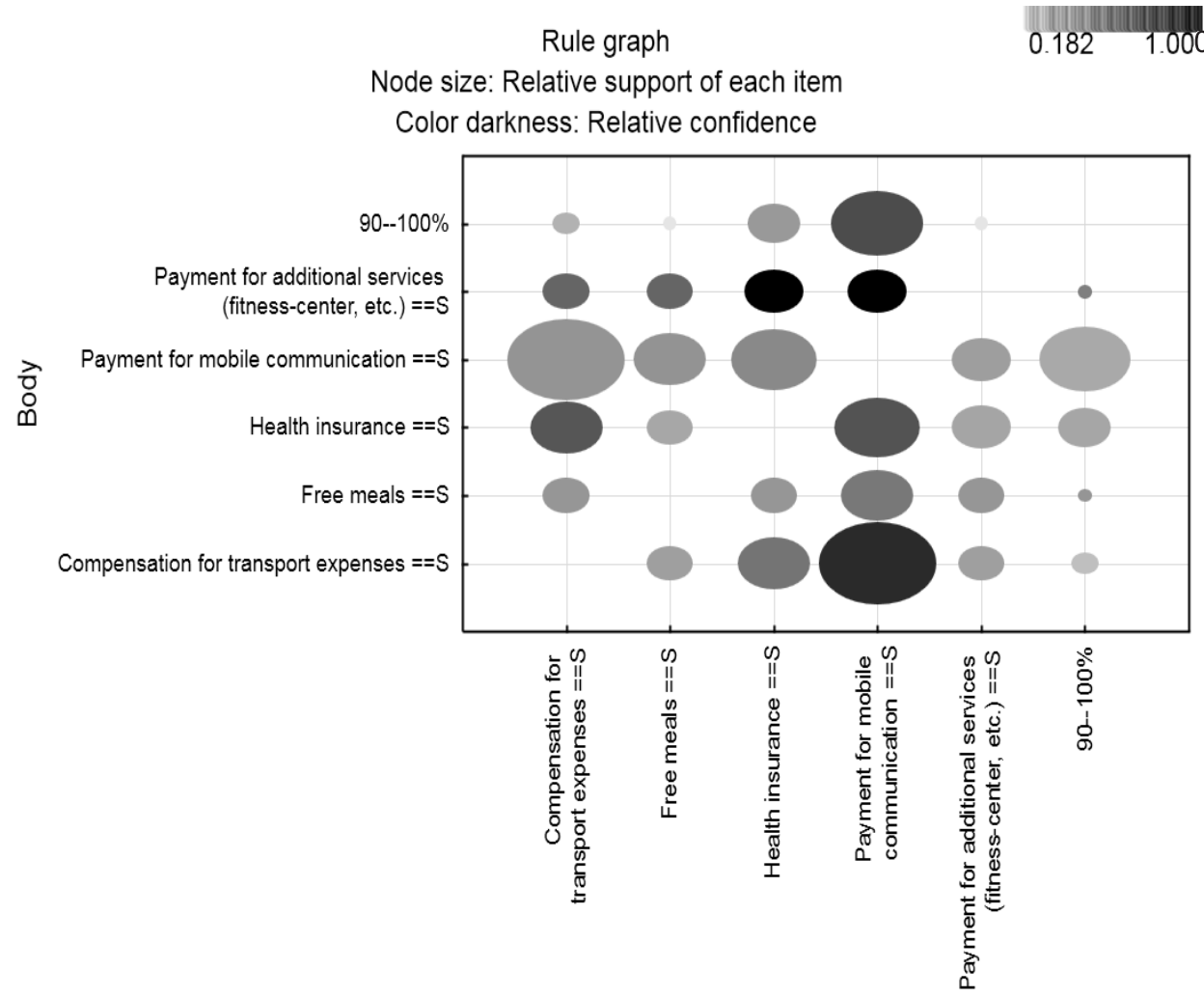

Head

Fig. 12. The diagram of association rules of satisfaction with options of employee benefits connected with PhP total $(90 \div 100 \%)$ satisfaction with employee benefits 


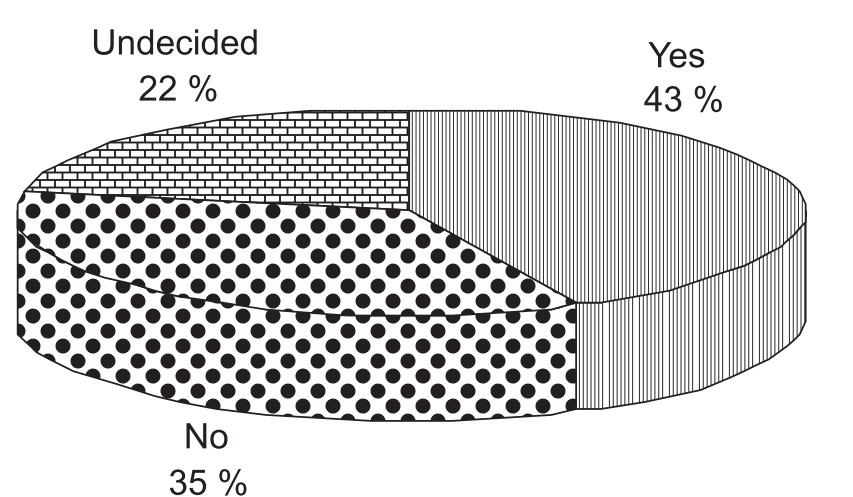

Yes Undecided

Fig. 13. The PhP opinions regarding the need to replace employee benefits used in pharmacy institutions

the three-dimensional projection will save $71.63 \%$ of the interactions between the indicators presented in the baseline conjugation table, and it is a really good indicator of the total inertia.

The analysis of the three-dimensional configuration obtained (Fig. 16) reflects clear distribution of the values of the indicators studied into three clusters: the lower left part of the graph is filled in with the points, which represent the absence of the need to replace employee benefits and the satisfaction with all of their options; the upper part shows the points, which represent the dissatisfaction with the options of employee benefits and the desire to replace them; the bottom right part of the graph is a cluster of points reflecting the corresponding unreached opinions regarding the need to replace employee benefits and the ambiguity of PhP thoughts concerning the satisfaction with their options.

In further analysis the most interesting and relevant questions were the characteristics distinguishing the pharmacy institutions where $\mathrm{PhP}$ were satisfied with the employee benefits received from the pharmacy institutions where $\mathrm{PhP}$ did not feel socially protected. For this purpose, the distances between the points corresponding to different degrees of satisfaction with the individual op- tions of employee benefits and the points where, in accordance with $\mathrm{PhP}$ opinion, it was necessary to make revision and replacement were considered. According to the mutual location of the points it was possible to estimate the degree of importance of separate options for forming the idea about the need to revise the benefits (the closer they were located, the stronger was interaction between them). For convenience to analyze the interactions observed they were represented at two-dimensional subspace (with two axes) (Fig. 17). The map shows the relationship between the importance of the options of employee benefits for two clusters of $\mathrm{PhP}$ with a certain opinion about the need to replace employee benefits in their pharmacy institution (there is no cluster for those who answered "Difficult to answer").

According to the resulting configuration of the points the conclusion can be made that in employee benefits required to be reviewed health insurance is the most important for $\mathrm{PhP}$ satisfaction, compensation for mobile communication and transport expenses are less important; payment for additional services and meals are of the least importance. When assessing employee benefits (which need to be replaced) the dissatisfaction with the payment for additional services has the greatest value, and the dissatisfaction with health insurance, compensation for transport expenses and mobile communication services, as well as payment for meals and free lunches are less valuable.

The coordinates of the points representing the parameters studied in the three-dimensional space of the final configuration was used for numerical estimation of these weights. Using the Euclidean metric the distances from the points representing the satisfaction/dissatisfaction with each option of employee benefits to the points representing the need to replace employee benefits or the absence of such need were calculated. The contribution of each option was assessed in inverse proportion to the calculated distance. The resulting ratios were adjusted in such way that they reflected the relative contribution of the satisfaction with each option to the satisfaction with employee benefits in general. The

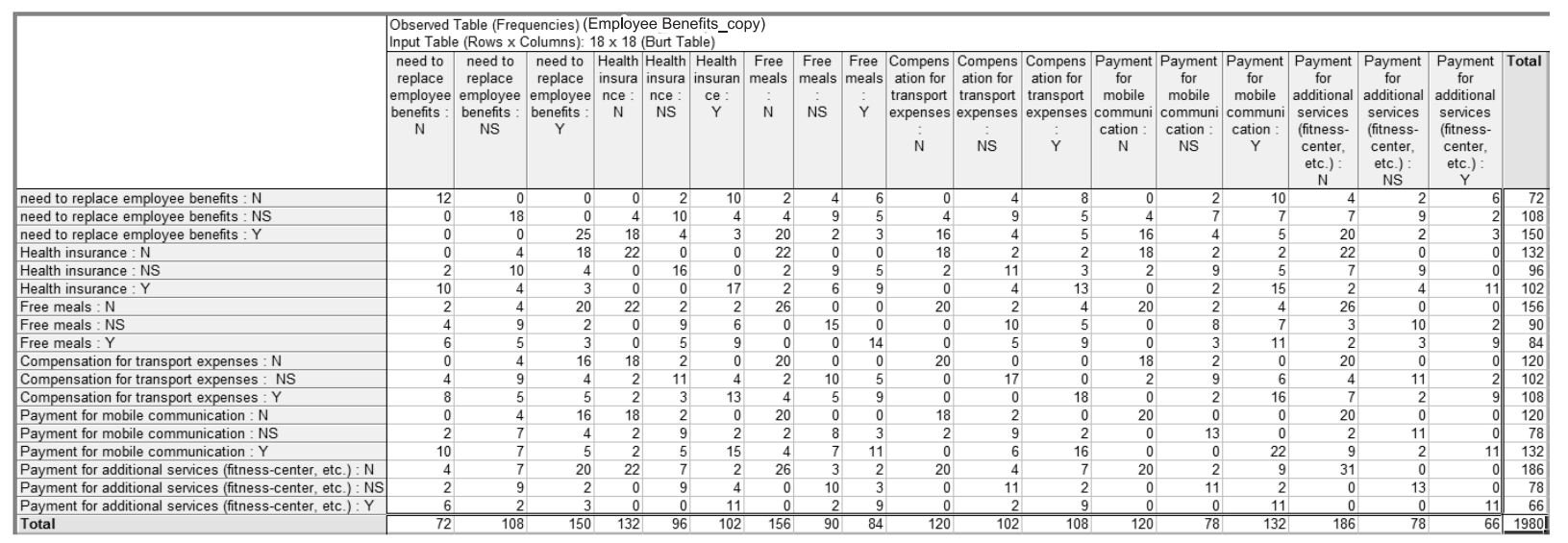

Fig. 14. The Burt matrix to study the interactions between the need to replace employee benefits and PhP satisfaction with their options Note (answers for the questions under analysis): $\mathrm{Y}$ - yes; N - no; NS - difficult to answer (not sure) 


\begin{tabular}{||l|l|l|l|r|r|}
\hline \multirow{2}{*}{$\begin{array}{l}\text { Number } \\
\text { of Dims. }\end{array}$} & \multicolumn{3}{|l}{$\begin{array}{l}\text { Eigenvalues and Inertia for all Dimensions (Employee Benefits) } \\
\text { Input Table (Rows } \times \text { Columns): } \\
\text { Total Inertia=2,0000 }\end{array}$} \\
\cline { 2 - 6 } & $\begin{array}{l}\text { Singular } \\
\text { Values }\end{array}$ & $\begin{array}{c}\text { Eigen- } \\
\text { Values }\end{array}$ & $\begin{array}{c}\text { Perc. of } \\
\text { Inertia }\end{array}$ & $\begin{array}{c}\text { Cumulatv } \\
\text { Percent }\end{array}$ & $\begin{array}{c}\text { Chi } \\
\text { Squares }\end{array}$ \\
\hline 1 & 0.870188 & 0.757228 & 37.86138 & 37.8614 & 695.3588 \\
\hline 2 & 0.725612 & 0.526513 & 26.32563 & 64.1870 & 483.4943 \\
\hline 3 & 0.385758 & 0.148810 & 7.44048 & 71.6275 & 136.6512 \\
\hline 4 & 0.376213 & 0.141536 & 7.07682 & 78.7043 & 129.9723 \\
\hline 5 & 0.335873 & 0.112811 & 5.64053 & 84.3449 & 103.5935 \\
\hline 6 & 0.316010 & 0.099862 & 4.99311 & 89.3380 & 91.7031 \\
\hline 7 & 0.294143 & 0.086520 & 4.32599 & 93.6640 & 79.4508 \\
\hline 8 & 0.231570 & 0.053625 & 2.68124 & 96.3452 & 49.2434 \\
\hline 9 & 0.180082 & 0.032430 & 1.62148 & 97.9667 & 29.7800 \\
\hline 10 & 0.142743 & 0.020375 & 1.01877 & 98.9855 & 18.7107 \\
\hline 11 & 0.123537 & 0.015261 & 0.76307 & 99.7485 & 14.0144 \\
\hline 12 & 0.070920 & 0.005030 & 0.25148 & 100.0000 & 4.6187 \\
\hline
\end{tabular}

Fig. 15. The Scree plot, eigenvalues and their inertia explained by them to choose the dimension of the space of the final configuration within the conditions of the multiple correspondence analysis of the need to replace employee benefits and the satisfaction with their options

3D Plot of Column Coordinates; Dimension: $1 \times 2 \times 3$ Input Table (Rows x Columns): $18 \times 18$ (Burt Table)

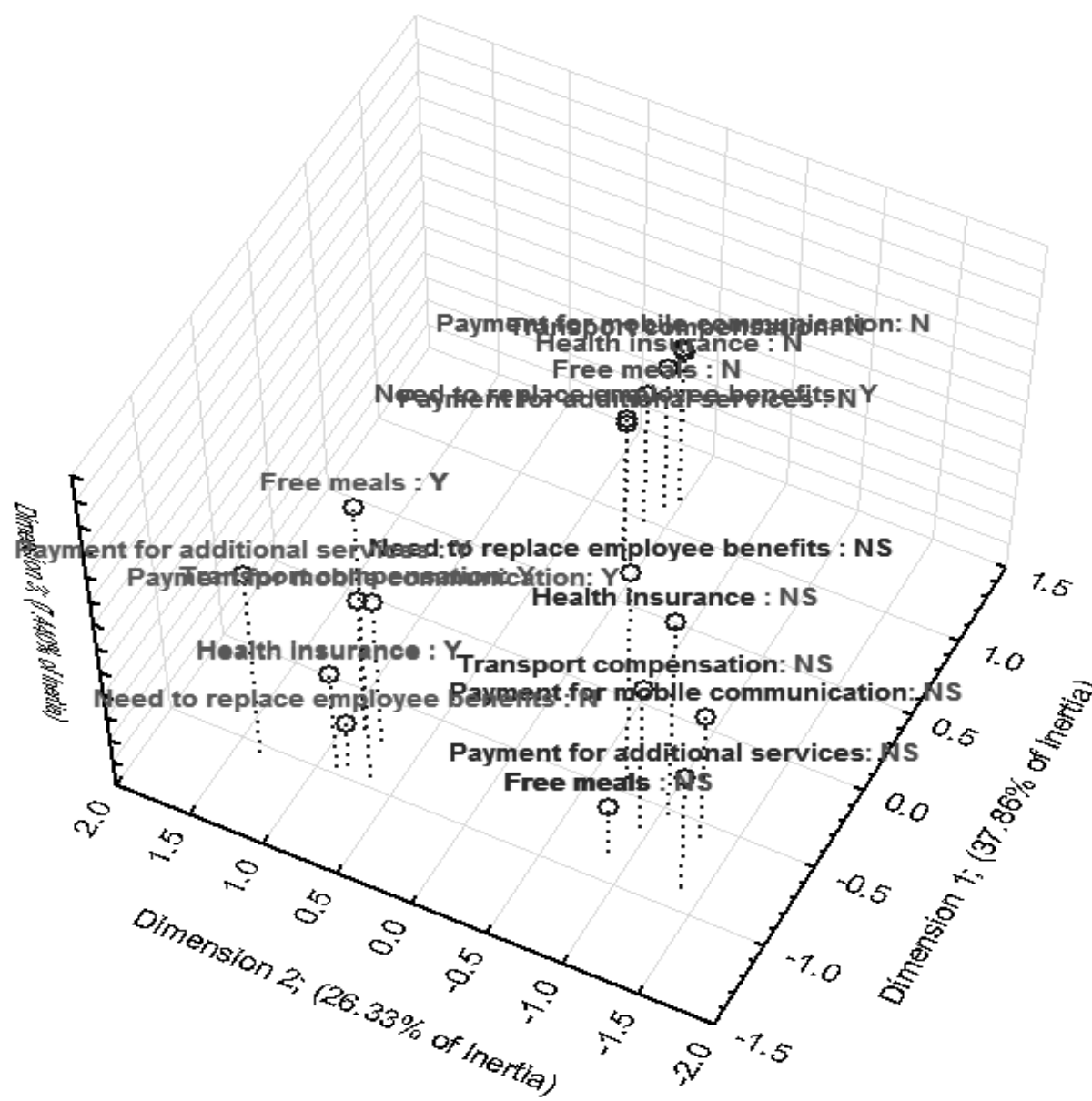

Fig. 16. The three-dimensional projection of the interactions of correspondences of the need to replace employee benefits and the satisfaction with their options 


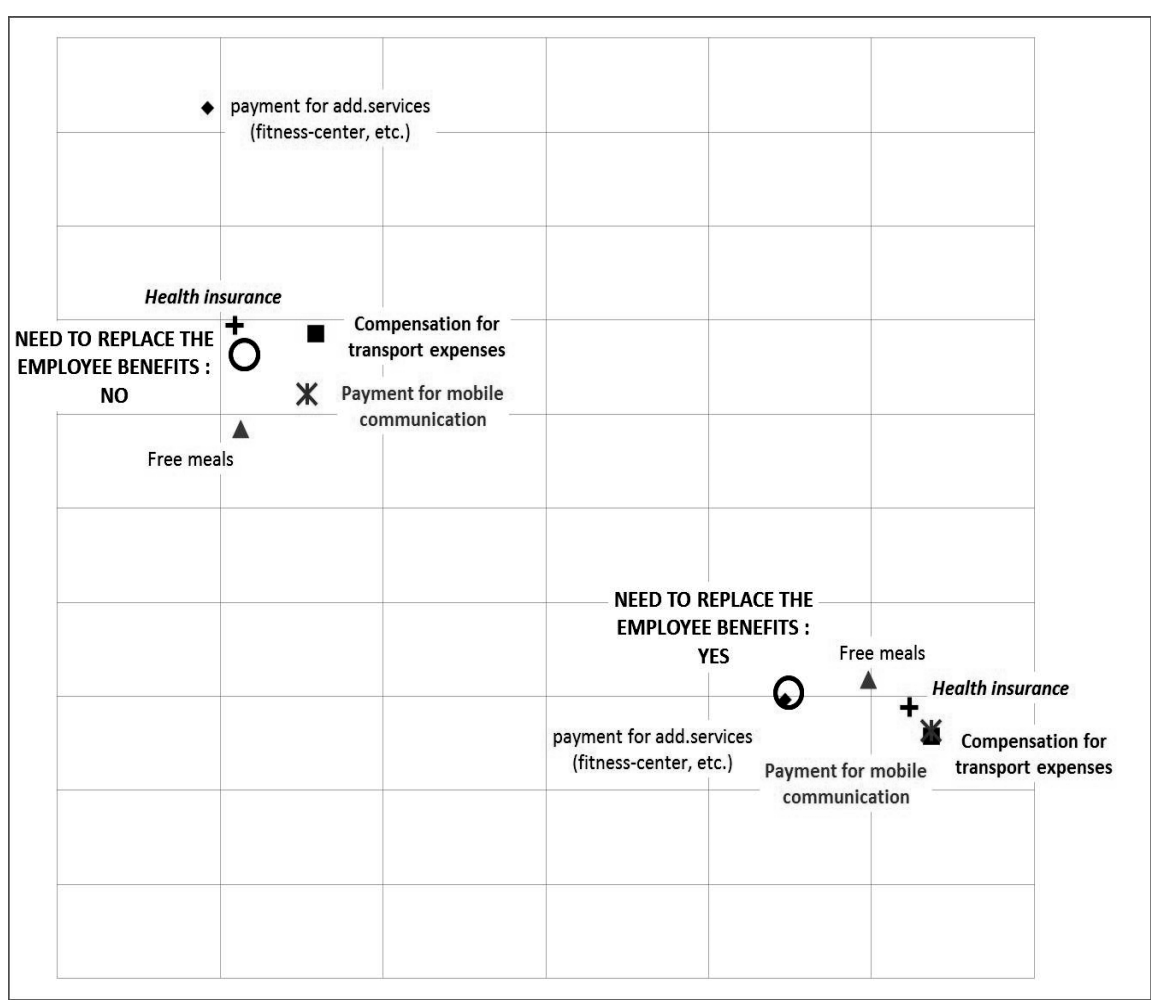

Fig. 17. The two-dimensional map of the interactions between the need to replace employee benefits of the pharmacy institution and PhP satisfaction with their options

results of calculations are shown in Tab. 2 and reflected by the diagram in Fig. 18.

Thus, PhP opinion regarding the need to replace employee benefits used by pharmacy institutions was studied. It was shown that there were direct interactions between PhP satisfaction with five basic options of employee benefits and their opinion regarding the need to review employee benefits.

The graphical representation of 153 interactions between the values of six indicators studied in the space of the reduced dimension was obtained using the multiple correspondence analysis. It allowed us to have the visual assessment and qualitative description of the importance degree of $\mathrm{PhP}$ satisfaction/dissatisfaction with

Table 2

The results of calculation of $\mathrm{PhP}$ satisfaction with individual options of employee benefits when there is no need to replace these employee benefits

\begin{tabular}{|l|c|c|}
\hline \multicolumn{1}{|c|}{$\begin{array}{c}\text { Option of employee } \\
\text { benefits }\end{array}$} & $\begin{array}{c}\text { Weighting } \\
\text { factor }\end{array}$ & $\begin{array}{c}\text { Relative } \\
\text { contribution (\%) }\end{array}$ \\
\hline Health insurance & 5.083 & 35.59 \\
\hline $\begin{array}{l}\text { Compensation for } \\
\text { transport expenses }\end{array}$ & 3.692 & 25.85 \\
\hline $\begin{array}{l}\text { Payment for mobile } \\
\text { communication }\end{array}$ & 3.240 & 22.69 \\
\hline $\begin{array}{l}\text { Payment for meals, } \\
\text { provision of free lunches }\end{array}$ & 1.856 & 13.00 \\
\hline $\begin{array}{l}\text { Payment for additional } \\
\text { services (fitness-centre, } \\
\text { etc.) }\end{array}$ & 0.410 & 2.87 \\
\hline
\end{tabular}

each component of employee benefits in order to form an opinion regarding the need for replacing employee benefits. The components of employee benefits were ranked by the degree of their importance in order to form the optimal set of SPPhP. The scheme for optimal allocation of the funds to employee benefits was proposed as an element of SPPhP by their individual options $[8,10,13,14]$.

The third phase of the study consists in planning the costs for employee benefits taking into account the regularities and the importance of each component identified at the previous phases. At this phase, according to the respondents, the analysis of desirable costs for individual options of employee benefits depending on PhP

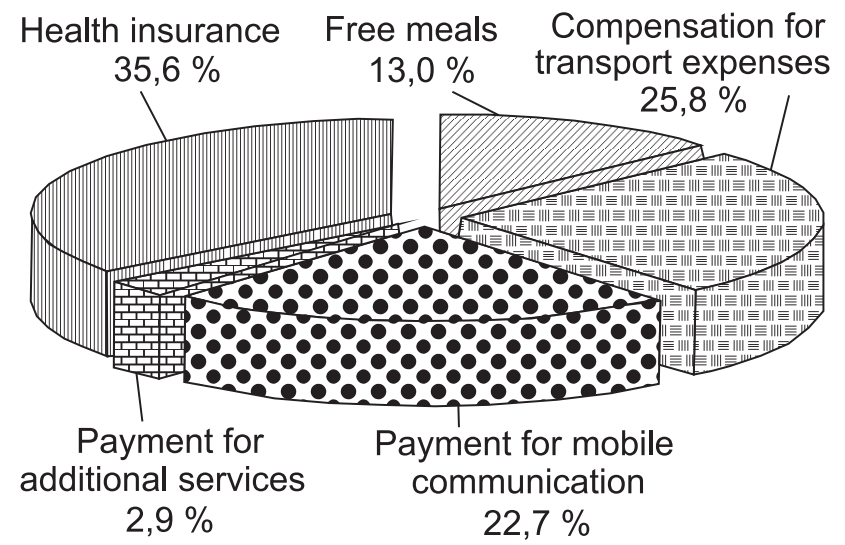

Fig. 18. The optimal distribution of costs for certain options of employee benefits providing PhP satisfaction in general 
Descriptive statistical characteristics of the total desirable cost for employee benefits depending on the level of the $\mathrm{PhP}$ position held

\begin{tabular}{|c|c|c|}
\hline \multirow{2}{*}{ The level of the PhP position held } & \multicolumn{2}{|c|}{ Cost of employee benefits (UAH/per year) } \\
\hline & $M \pm m$ & Me [LQ; UQ] \\
\hline $\begin{array}{l}\text { The 1-st }{ }^{* 2, * 4, * 6} \\
\text { (pharmaceutist, pharmacist) }\end{array}$ & $1236.36 \pm 45.03$ & $1200[1100 ; 1200]$ \\
\hline $\begin{array}{l}\text { The 2-nd-3-rd }{ }^{* 1, * 6} \\
\text { (senior pharmaceutist, head of the department) }\end{array}$ & $2718.61 \pm 125.65$ & $2800[1800 ; 3500]$ \\
\hline $\begin{array}{l}\text { The 4-th-5-th*1,*6 } \\
\text { (deputy heads, head of a pharmacy, authorized person) }\end{array}$ & $4351.16 \pm 238.52$ & $4800[2500 ; 5600]$ \\
\hline $\begin{array}{l}\text { The } 6-\operatorname{th}^{*} 1,{ }^{*} 2,{ }^{*} 1,{ }^{*} 4 \\
\text { (head of a pharmacy institution, head of a pharmacy } \\
\text { warehouse (base), director) }\end{array}$ & $5890.92 \pm 504.65$ & $5601[3300 ; 5601]$ \\
\hline
\end{tabular}

Note: $\mathrm{M}$ - is the sample mean, $\mathrm{m}$ - is the standard error of the mean; $\mathrm{Me}$ - is the median, $\mathrm{LQ}$ - is the lower quartile, $\mathrm{UQ}$ - is the upper quartile; ${ }^{*} 1$ - is the significant difference from the costs for social benefits of PhP positions of the 1-st level; ${ }^{*} 2$ - is the significant difference from the costs for social benefits of $\mathrm{PhP}$ positions of the 2-nd-3-rd level; *4 - is the significant difference from the costs for social benefits of PhP positions of the 4-th-5-th level; * 6 - is the significant difference from the costs for social benefits of PhP positions of the $6^{\text {th }}$ grade.

position was conducted. According to these data the estimated total cost of employee benefits for the considered positions was separately calculated [11-14].

Previously the descriptive statistical analysis of the desirable expenses was conducted (Tab. 3). Due to the fact that none of the indicators were characterized by the standard statistical law along with the mean values their central tendencies were characterized by the median, while the deviation from the centre - by $25 \%$ percentiles (quartiles).

The Friedman dependent samples ANOVA showed a high statistical significance of the differences in the total cost of employee benefits for $\mathrm{PhP}$ positions of different levels $(\chi 2(\mathrm{~N}=84, \mathrm{df}=3)=41.4483, \mathrm{p}=0.00000<<0.05)$. The pairwise intergroup comparisons of the costs of employee benefits conducted to elaborate the revealed differences using Wilcoxon criterion under Bonferroni correction for the comparative multiplicity showed the significance of the differences between all groups except for the positions of the 2-nd-3-rd and 4-th-5-th levels $(\mathrm{Z}=2.2014, \mathrm{p}=0.027709>0.0083333=0.05 / 6)$. It allowed writing down the following number of advantages for the desired total cost of employee benefits depending on the position of $\mathrm{PhP}$ : the cost of the 1-st level $<$ the cost of the 2-nd-3-rd level = the cost of the 4-th5 -th level $<$ the cost of the 6-th level.

Thus, the conclusion can be made that the total desirable cost of employee benefits according to the respondent opinion should increase depending on the level of their position held. Moreover, the increase is sta-

Box Plot of multiple variables

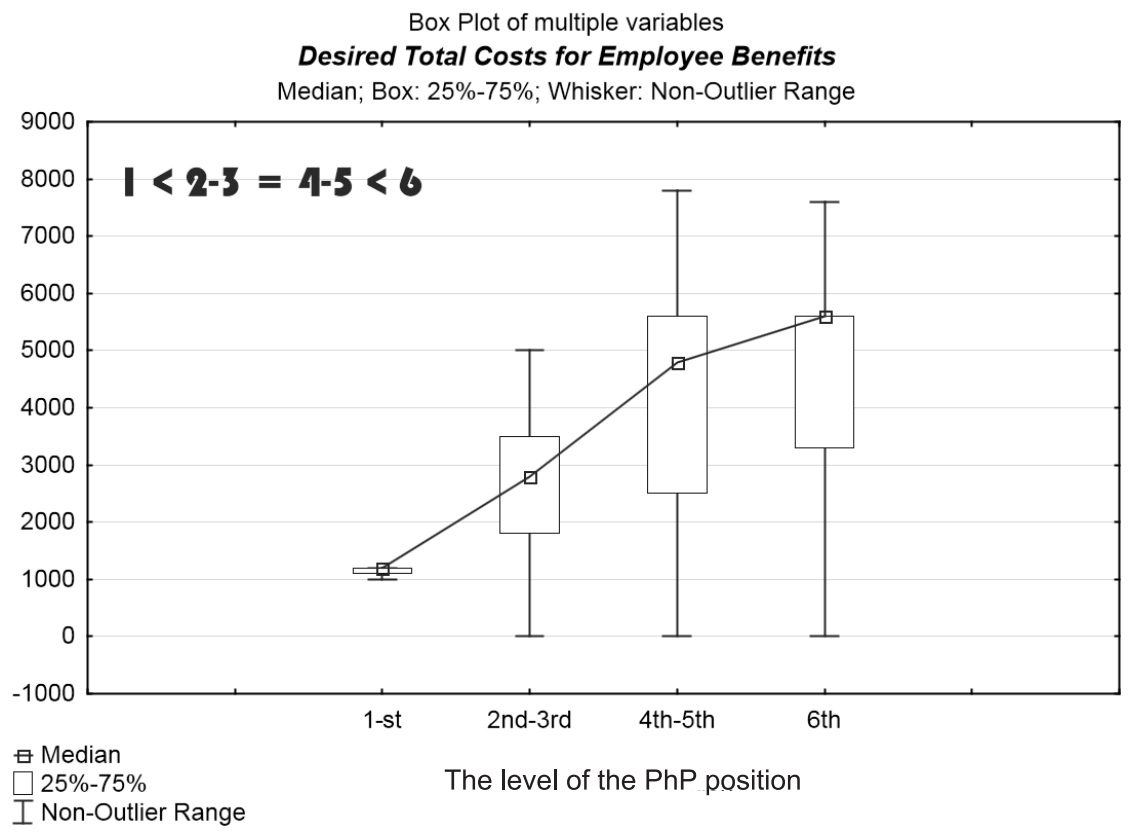

Fig. 19. The graph of the total cost of employee benefits depending on the level of the PhP position held 
The proposed optimal cost of the options of the employee benefits depending on the level of the position of the pharmacy professional held (UAH per year)

\begin{tabular}{|c|c|c|c|c|}
\hline \multirow[b]{2}{*}{$\begin{array}{l}\text { Options of employee } \\
\text { benefits }\end{array}$} & \multicolumn{4}{|c|}{ The level of the PhP position held } \\
\hline & $\begin{array}{l}\text { The 1-st level } \\
\text { (pharmaceutist, } \\
\text { pharmacist) }\end{array}$ & $\begin{array}{l}\text { The 2-nd-3-rd level } \\
\text { (senior pharmaceutist, } \\
\text { head of the } \\
\text { department) }\end{array}$ & $\begin{array}{l}\text { The 4-th-5-th level } \\
\text { (deputy heads, } \\
\text { head of a pharmacy, } \\
\text { authorized person) }\end{array}$ & $\begin{array}{l}\text { The 6-th level (head } \\
\text { of a pharmacy } \\
\text { institution, head of a } \\
\text { pharmacy warehouse } \\
\text { (base), director) }\end{array}$ \\
\hline $\begin{array}{l}\text { Health insurance, } \\
\text { life insurance }\end{array}$ & $\begin{array}{c}427.13 \text { [391.53; } \\
427.13]\end{array}$ & $\begin{array}{c}996.63 \text { [640.69; } \\
1245.79]\end{array}$ & $\begin{array}{c}1708.51 \text { [889.85; } \\
1993.26]\end{array}$ & $\begin{array}{c}1993.62[1174.60 \\
1993.62]\end{array}$ \\
\hline $\begin{array}{l}\text { Compensation for } \\
\text { transport expenses }\end{array}$ & $\begin{array}{c}310.19[284.35 ; \\
310.19]\end{array}$ & $\begin{array}{c}723.79[465.29 \\
904.73]\end{array}$ & $\begin{array}{c}1240.78 \text { [646.24; } \\
1447.58]\end{array}$ & $\begin{array}{c}1447.83 \text { [853.04; } \\
1447.83]\end{array}$ \\
\hline $\begin{array}{l}\text { Payment for mobile } \\
\text { communication }\end{array}$ & $\begin{array}{c}272.23[249.55 \\
272.23]\end{array}$ & $\begin{array}{c}635.21[408.35 \\
794.01]\end{array}$ & $\begin{array}{c}1088.93[567.15 ; \\
1270.42]\end{array}$ & $\begin{array}{c}1270.65 \text { [748.64; } \\
1270.65]\end{array}$ \\
\hline Free lunches & $\begin{array}{c}155.98[142.98 ; \\
155.98]\end{array}$ & $\begin{array}{c}363.95[233.97 ; \\
454.94]\end{array}$ & $\begin{array}{c}623.91[324.96 ; \\
727.90]\end{array}$ & $\begin{array}{c}728.03[428.94 ; \\
728.03]\end{array}$ \\
\hline $\begin{array}{l}\text { Payment for vacation } \\
\text { voucher and other } \\
\text { additional services }\end{array}$ & $34.47[31.59 ; 34.47]$ & $80.42[51.70 ; 100.52]$ & $137.86[71.80 ; 160.84]$ & $160.87[94.78 ; 160.87]$ \\
\hline Total. UAH per year & $1200[1100 ; 1200]$ & $2800[1800 ; 3500]$ & $4800[2500 ; 5600]$ & $5601[3300 ; 5601]$ \\
\hline
\end{tabular}

tistically significant among professionals, who hold positions of the 1-st and 2-nd levels, as well as among professionals, who occupy positions of the 4-th-5-th levels, in comparison with the heads of pharmacy institutions and directors (the 6-th level). The difference in the cost of employee benefits for professionals of the 2-nd-3-rd levels compared to those of the 4-th-5-th levels is not statistically significant (Tab. 3, Fig. 19) [13].

According to the data obtained regarding the desired total cost of employee benefits and the scheme of optimal distribution of total costs for individual options developed at the previous phase, which provide the greatest satisfaction with employee benefits (Tab. 2, Fig. 18), the following calculation of the cost of employee benefits for $\mathrm{PhP}$ depending on the position held can be proposed (Tab. 4).

\section{CONCLUSIONS}

Using the methods of multidimensional statistical analysis and Data Mining the interaction between satisfaction with employee benefits in a pharmacy institution by pharmacy professionals $(\mathrm{PhP})$ and the need to provide or review the current employee benefits and general satisfaction with it have been studied in the article.
The analysis of association rules has made it possible to identify stable blocks of interactions between individual options, which are peculiar to different degree of $\mathrm{PhP}$ satisfaction with employee benefits, and determine factors associated to the greatest extent with poor, medium, high and total $\mathrm{PhP}$ satisfaction with employee benefits.

The weight loads of individual components (options) of employee benefits have been calculated in order to form the balanced composition by calculating the distances on the map of the relations of the parameters studied in the space of the reduced dimension obtained as a result of using the multiple correspondence analysis.

Based on the proposed scheme of the optimal filling of employee benefits the cost calculation has been made for their options, which provide the desired total cost of employee benefits estimated taking into account the data from the survey of PhP questionnaires in the pharmacy institutions of different forms of ownership. Four types of expenses have been offered depending on the position held by $\mathrm{PhP}$.

Conflict of Interests: authors have no conflict of interests to declare.

\section{REFERENCES}

1. Зарічкова, М. В. Необхідність впровадження соціальних гарантій працівників охорони здоровя на рівні розвинутих європейських держав / М. В. Зарічкова // Фармація XXI століття : тенденції та перспективи. Матер. VIII Нац. з’їзду фармацевтів України, 13-16 вересня 2016 р. - Х., 2016. - С. 219-220.

2. Про соціальні послуги: закон України від 19.06.2003 №966-IV [Електронний ресурс]. - Режим доступу : http://www.zakon.rada.gov.ua

3. Про оплату праці : Закон України від 24 березня 1995 року № 108/95-ВР [Електронний ресурс]. - Режим доступу : http://www. zakon.rada.gov.ua

4. Про збір та облік єдиного внеску на загальнообов'язкове державне соціальне страхування : Закон України від 8 липня 2010 року № 2464-VI [Електронний ресурс]. - Режим доступу : http://www.zakon.rada.gov.ua

5. Кодекс законів про працю України від 10.12 .71 р. № 322-VIII із змінами і доповненнями [Електронний ресурс]. - Режим доступу : http://www.zakon.rada.gov.ua

6. Про колективні договори і угоди із змінами і доповненнями : Закон України від 01.07.1993 р. № 3356-XII [Електронний ресурс]. - Режим доступу : zakon.rada.gov.ua 
7. Про охорону праці : Закон України від 14.10.1992 p. № 2694-XII [Електронний ресурс]. - Режим доступу : http://www.zakon.rada.gov.ua

8. Zarichkova, M. V. Analysis of the attitude of pharmacy specialists towards the current social protection system and directions for its reformation / M. V. Zarichkova // Вісник фармації. - 2015. - № 1 (81). - P. 55-59. doi: 10.17686/sced_rusnauka_2015-387

9. Зарічкова, М. В. Соціальний пакет як елемент додаткових соціальних гаранитій для спеціалістів фармації в умовах економічної кризи / М. В. Зарічкова // Соціальна фармація : стан, проблеми та перспективи : Матер. II Міжнар. наук.-практ. Інтернет-конф., 27-30 квітня 2015 р. - Х. : НФаУ, 2015. - С.257-260.

10. Толочко, В. М. Дослідження етапів формування та складових елементів соціального пакету як елементу додаткових соціальних гарантій для спеціалістів фармації // В. М. Толочко, М. В. Зарічкова // Соціальна фармація в охороні здоров'я. - 2016. - Т. 2, № 4. - C. 48-57.

11. Зарічкова, М. В. Впровадження соціального пакету в аптечні заклади України: визначення та порядок обліку / М. В. Зарічкова // Актуальні проблеми розвитку галузевої економіки та логістики. Матер. V міжнар. наук.-практ. конференції 3 міжнар. участю (м. Харків, 20-21 квітня 2017 р.) - Х. : НФаУ, 2017. - С. 355 - 358.

12. Котова, Н. І. Підходи до формування соціального пакета як сучасного інструменту мотивації працівників / Н. І. Котова, А. В. Нікуліна // Вісник економічної науки України. - 2014. - № 2 (53). - С.52-57.

13. Толочко, В. М. Обгрунтування етапів формування та складових елементів соціального пакету працівників фармацевтичного сектора галузі охорони здоров’я : метод. рек. / В. М. Толочко, М. В. Зарічкова. - К. : Укрмедпатентінформ, $2017 .-20$ с.

14. Тяжельникова, Е. Социальный пакет : виды и способы / Е. Тяжельникова // Секретарь-референт [Электронный ресурс] :- Режим доступа : http://www.hr-portal.ru/article/socialnyy-paket-vidy-i-sposoby

15. Зарічкова, М. В. Дослідження законодавчо-нормативного регулювання соціального захисту працівників фармацевтичної галузі України / М. В. Зарічкова, В. М. Толочко, Т. Ф. Музика : метод. рек. - Х. : НФаУ, 2015. - 32 с.

16. Зарічкова, М. В. Удосконалення організації надання соціальних послуг спеціалістам фармації / М. В. Зарічкова // Фармацевтичний часопис. - 2015. - № 3 (35). - С.48-57.

\section{REFERENCES}

1. Zarichkova, M. V. (2016). Farmatsiia XXI stolittia: tendentsii ta perspektyvy. Kharkiv: NUPh, 219-220.

2. Zakon Ukrainy vid 19.06.2003 r. № 966-IV. Pro sotsialni posluhy. Available at: http://www.zakon.rada.gov.ua

3. Zakon Ukrainy vid 24.03.1995 r. № 108-VR. Pro oplatu pratsi. Available at: http://www.zakon.rada.gov.ua

4. Zakon Ukrainy vid 08.07.2010 r. № 2464-VI. Pro zbir ta oblik yedynoho vnesku na zahalnooboviazkove derzhavne sotsialne strakhuvannia. Available at: http://www.zakon.rada.gov.ua

5. Kodeks zakoniv pro pratsiu Ukrainy vid 10.12.71 r. № 322-VIII iz zminamy ta dopovnenniamy. Available at: http://www.zakon.rada.gov.ua

6. Zakon Ukrainy vid 01.07.1993 r. № 3356-XII. Pro kolektyvni dohovory i uhody iz zminamy i dopovnenniamy. Available at: zakon. rada.gov.ua

7. Zakon Ukrainy vid 14.10.1992 r. № 2694-XII. Pro okhoronu pratsi. Available at: http://www.zakon.rada.gov.ua

8. Zarichkova, M. V. (2015). Analysis of the attitude of pharmacy specialists towards the current social protection system and directions for its reformation. Visnik farmaciï, 1 (81), 55-59. doi: 10.17686/sced_rusnauka_2015-387

9. Zarichkova, M. V. (2015). Sotsiala Farmatsiia. Kharkiv: NUPh, 257-260.

10. Tolochko, V. M., Zarichkova, M. V. (2016). Sotsialna farmatsiia v okhoroni zdorovia, 2 (4), 48-57.

11. Zarichkova, M. V. (2017). Aktualni problemy rozvytku haluzevoi ekonomiky ta lohistyky. Kharkiv: NUPh, 355 - 358.

12. Kotova, N. I., Nikulina, A. V. (2014). Visnyk ekonomichnoi nauky Ukrainy, 2 (53), 52-57.

13. Tolochko, V. M., Zarichkova, M. V. (2017). Obgryntuvannia etapiv formuvannia ta skladovykh elementiv sotsialnoho paketu pratsivnykiv farmatsevtychnoho sektory haluzi okhorony zdorovia. Kyiv: Ukrmedpatentinform, 20.

14. Tiazhelnikova, Ye. Secretar-Referent. Available at: http://www.hr-portal.ru/article/socialnyy-paket-vidy-i-sposoby

15. Zarichkova, M. V., Tolochko, V. M., Muzyka, T. F. (2015). Doslidzhennia zakonodavch-normatyvnoho rehuliuvannia sotsilnoho zakhystu pratsivnykiv farmatsevtychnoi haluzi Ukrainy. Kharkiv: NUPh, 32.

16. Zarichkova, M. V. (2015). Farmatsevtychnyi chasopys, 3 (35), 48-57.

Information about authors:

Zarichkova M. V., Candidate of Pharmacy (Ph.D.), assistant professor of the Department of Management and Economics of Pharmacy, Institute for Continuing

Education of Pharmacy Professionals, National University of Pharmacy. E-mail: itl760@online.kharkov.ua. ORCID - http://orcid.org/0000-0001-7980-5669

Відомості про авторів:

Зарічкова М. В., канд. фарм. наук, доцент кафедри управління та економіки фармації Інституту підвищення кваліфікації спеціалістів фармації,

Національний фармацевтичний університет. E-mail: itl760@online.kharkov.ua. ORCID - http://orcid.org/0000-0001-7980-5669

Сведения об авторах:

Заричковая М. В., канд фарм. наук, доцент кафедры управления и экономики фармации Института повышения квалификации специалистов фармации,

Национальный фармацевтический университет. E-mail: itl760@online.kharkov.ua. ORCID - http://orcid.org/0000-0001-7980-5669 